УДК 656.71

РУБЛЕВ ВЛАДИМИР ВЛАДИМИРОВИЧ

аспирант кафедры Предпринимательства и логистики Российского экономического университета им. Г.В. Плеханова (2. Москва),

e-mail:v.v.rublev@yandex.ru

ЛАРИН ОЛЕГ НИКОЛАЕВИЧ

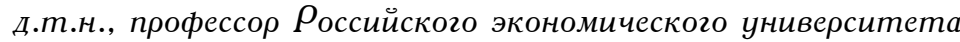

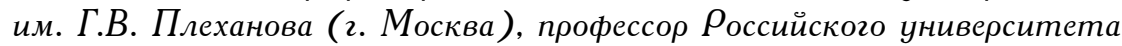
транспорта (2. Москва), Академик академий транспорта, e-mail: larin_on@mail.ru

DOI:10.26726/1812-7096-2021-9-34-44

\title{
ПЕРСПЕКТИВЫ РАЗВИТИЯ АЭРОПОРТОВ ОСТРОВА КОРСИКА (ФРАНЦИЯ) В УСАОВИИ МАКРОЭКОНОМИЧЕСКОЙ НЕСТАБИАЬНОСТИ
}

Аннотауия. Шель работы. Шелью проводимого исследования является анализ деятельности аэропортов острова Корсика. Авиасообщение для островных территорий является одним из ключевых элементов транспортной логистики. В условиях преодоления кризиса 2020 2. падение пассажиропотока на франиузском рынке пассажирских авиаперевозок превысило 60\%, что стало наихудшим показателем за всю историю развития гражданской авиации. Методология и методы проведения работы. На основании анали-

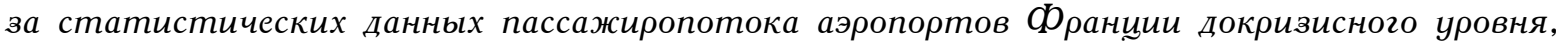
на основании анализа маршрутной сети аэропортов Корсики в условиях преодоления кризиса, а также на основании данных авиакомпании «Air Corsica» (региональной авиакомпании СDраниии, базирующейся на территории островных аэропортов) было пред-

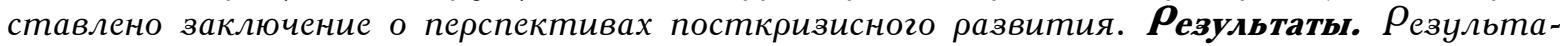
том проведенного исследования стало заключение о необходимости развития маршрутной сети аэропортов Корсики при условии расширения сотрудничества с ведущиими европейскими бюджетными авиакомпаниями. В качестве позитивного опыта развития островных аэропортов представлен анализ международной маршрутной сети аэропорта Кальяри (остров Сардиния, Италия). Область применения результатов. Результаты проведенного исследования могут быть применимы при разработке стратегии развития аэропорта Симферополь в условиях преодоления кризиса 2020 г. Выводы. преодоления кризиса 2020 г., вызванного негативным влиянием пандемии COVID-19, может стать банкротство региональной франиузской авиакомпании «Air Corsica» на фоне падения пассажиропотока и неразвитости маршрутной сети авиакомпании. Возможным эффективным сиенарием развития аэропортов Корсики может стать расиирение внутренней и международной маршрутной сети.

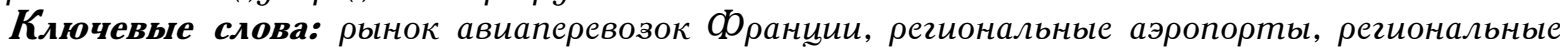
авиаперевозки, бюджетные авиакомпании, региональные авиакомпании, антикризисное управление.

RUBLEV VLADIMIR VLADIMIROVICH

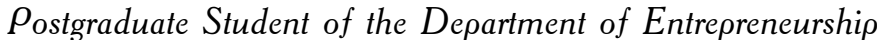
and Logistics of the Plekhanov Russian University of Economics (Moscow), e-mail:v.v.rublev@yandex.ru

LARIN OLEG NIKOLAEVICH

Dr.Sc of Technics, $\rho_{\text {rofessor of the Plekhanov Russian University }}$ of Economics (Moscow), Professor of the Russian University 


\section{of Transport (Moscow), Academician of the Russian} and International Academies of Transport, e-mail: larin_on@mail.ru

\section{PROSPECTS FOR THE DEVELOPMENT OF CORSICA ISLAND AIRPORTS (FRANCE) IN CONDITIONS OF MACROECONOMIC INSTABILITY}

Abstract. The purpose of the work. The purpose of the study is to analyze the activities of Corsica Island airports. Air traffic for island territories is one of the key elements of transport logistics. In the conditions of overcoming the crisis of 2020, the drop in passenger traffic in the French passenger air transportation market exceeded 60\%, which was the worst indicator in the history of the development of civil aviation. Methodology and methods of work. Based on the analysis of statistical data on the passenger traffic of French airports at the pre-crisis level, based on the analysis of the route network of Corsica airports in the conditions of overcoming the crisis, as well as on the basis of data from Air Corsica (a regional airline of France based on the territory of island airports), a conclusion was presented on the prospects for post-crisis development. Results. The result of the study was the conclusion that it is necessary to develoo the route network of Corsica airports, provided that cooperation with leading European budget airlines is expanded. The analysis of the international route network of Cagliari Airport (Sardinia Island, Italy) is presented as a positive experience of the development of island airports. The scope of the results. The results of the study can be applied in the development of a strategy for the development of Simferopol Airport in the conditions of overcoming the crisis of 2020. Conclusions. The result of overcoming the crisis of 2020 caused by the negative impact of the COVID-19 pandemic may be the bankruptcy of the regional French airline "Air Corsica" against the background of falling passenger traffic and the underdevelopment of the airline's route network. A possible effective scenario for the development of Corsica airports may be the expansion of the domestic and international route network.

Keywords: French air transportation market, regional airports, regional air transportation, budget airlines, regional airlines, crisis management.

Введение. Остров Корсика является территорией Республики Франция и входит в число ключевых туристических достопримечательностей Европы. На территории Корсики функционируют четыре региональных аэропорта, обслуживающих внутренние и международные (европейские) регулярные и чартерные рейсы. Совокупный пассажиропоток аэропортов острова по итогам докризисного 2019 г. составил 4263381 пасс. Представим данные пассажиропотока аэропортов Франции по итогам деятельности за 2019 г. (табл. 1) в сравнении с 2018 г.

Мы видим, что аэропорты Корсики не входят в число ведущих аэропортов Франции, однако на территории острова, как указано выше, действуют 4 аэропорта. К примеру, на территории острова Сардиния (Италия) действуют три региональных аэропорта: Кальяри, Ольбия, Альгеро. При этом Сардиния значительно превосходит остров Корсика по территории. Пассажиропоток аэропортов о. Корсика в 2019 г. был на уровне показателей 2018 г., что свидетельствует об отсутствии тенденции развития маршрутной сети.

Покажем аэропорты острова Корсика на карте (рис. 1).

Основной туристический поток Корсики составляют граждане Франции, Бельгии, Швейцарии и Италии. Стоимость пребывания на острове «Иль де боте» значительно выше, чем на островах Сицилия и Сардиния. Этим и обусловлен низкий показатель пассажиропотока, а также незначительная доля иностранных туристов в структуре туристического потока. Для подтверждения этого рассмотрим количество ночей пребывания туристов на территории о. Корсика в 2019 г.: ночи пребывания французских туристов (рис. 2), ночи пребывания зарубежных туристов (рис. 3).

Туризм является важной составляющей экономики острова. Более $30 \%$ населения работает на предприятиях в сфере услуг. Население острова, по данным на 2019 г., составляло 330 тыс. жителей [4]. Помимо туризма на территории острова действуют аграрные предприятия по выращиванию фруктов: яблок, персиков, нектарин, мандарин и овощей, а также осуществляется 
РУБЛЕВ В.В. ЛАРИН О.Н.

ПЕРСПЕКТИВЫ РАЗВИТИЯ АЭРОПОРТОВ ОСТРОВА КОРСИКА (ФРАНЦИЯ) В УСЛОВИИ МАКРОЭКОНОМИЧЕСКОЙ НЕСТАБИЛЬНОСТИ

Таблица 1

\begin{tabular}{|c|c|c|}
\hline Аэропорт & Пассажиропоток, чел. & \%, 2019 / 2018 гг. \\
\hline г. Париж (Шарль де Голль) & 76150007 & $+5,4$ \\
\hline г. Париж (Орли) & 31853049 & $-3,8$ \\
\hline г. Ницца & 14485423 & $+4,6$ \\
\hline г. Лион & 11739600 & $+6,4$ \\
\hline г. Марсель & 10151743 & $+8,1$ \\
\hline г. Тулуза & 9620224 & $-0,1$ \\
\hline г. Базель - Мюлуз & 9094821 & $+6,0$ \\
\hline г. Бордо & 7703135 & $+13,3$ \\
\hline г. Нант & 7227411 & $+16,6$ \\
\hline г. Париж (Бове) & 3983250 & $+5,2$ \\
\hline г. Лилль & 2189221 & $+5,3$ \\
\hline г. Монпелье & 1935631 & $+3,0$ \\
\hline г. Аяччо (о. Корсика) & 1618723 & $-3,3$ \\
\hline г. Бастия (о. Корсика) & 1559492 & $+2,3$ \\
\hline г. Страсбург & 1301886 & $+0,4$ \\
\hline г. Брест & 1236121 & $+11,9$ \\
\hline г. Биариц & 1066204 & $-9,9$ \\
\hline г. Ренн & 851976 & $-0,6$ \\
\hline г. Фигари (о. Корсика) & 748652 & $-1,0$ \\
\hline г. По & 606003 & $-1,1$ \\
\hline г. Тулон & 507199 & $-11,1$ \\
\hline г. Тарб & 466235 & $+0,9$ \\
\hline г. Периньян & 447938 & $-3,3$ \\
\hline г. Клермон-Ферран & 431180 & $+0,1$ \\
\hline г. Каркассон & 351982 & $-6,2$ \\
\hline г. Кальви (о. Корсика) & 336514 & $+0,4$ \\
\hline г. Гренобль & 307979 & $-13,5$ \\
\hline г. Кан & 304769 & $+11,2$ \\
\hline г. Лимож & 300840 & $-0,2$ \\
\hline г. Бержерак & 285182 & $-0,4$ \\
\hline г. Бези & 267712 & $+14,5$ \\
\hline г. Мец & 263619 & $-5,4$ \\
\hline г. Ля Рошель & 233001 & $-3,0$ \\
\hline г. Ним & 231031 & $-3,0$ \\
\hline г. Шамбери & 204573 & $-0,1$ \\
\hline г. Тур & 197109 & $+8,6$ \\
\hline г. Довиль & 134612 & $-8,7$ \\
\hline г. Потьё & 114134 & $-4,4$ \\
\hline 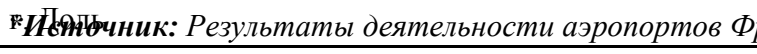 & 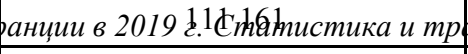 & aфик [1]. $+3,4$ \\
\hline$\longrightarrow$ & 102586 & $-17,2$ \\
\hline
\end{tabular}




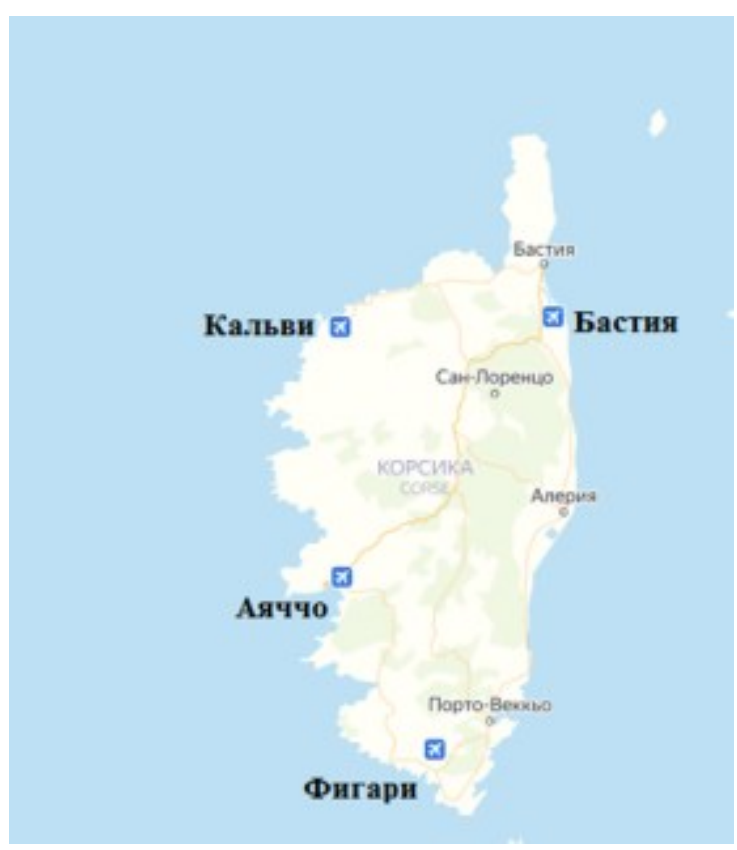

Puc. 1. Аэропорты острова Корсика на карте Источник: Carte touristique de la Corse (фр. Туристическая карта Корсики) [2].

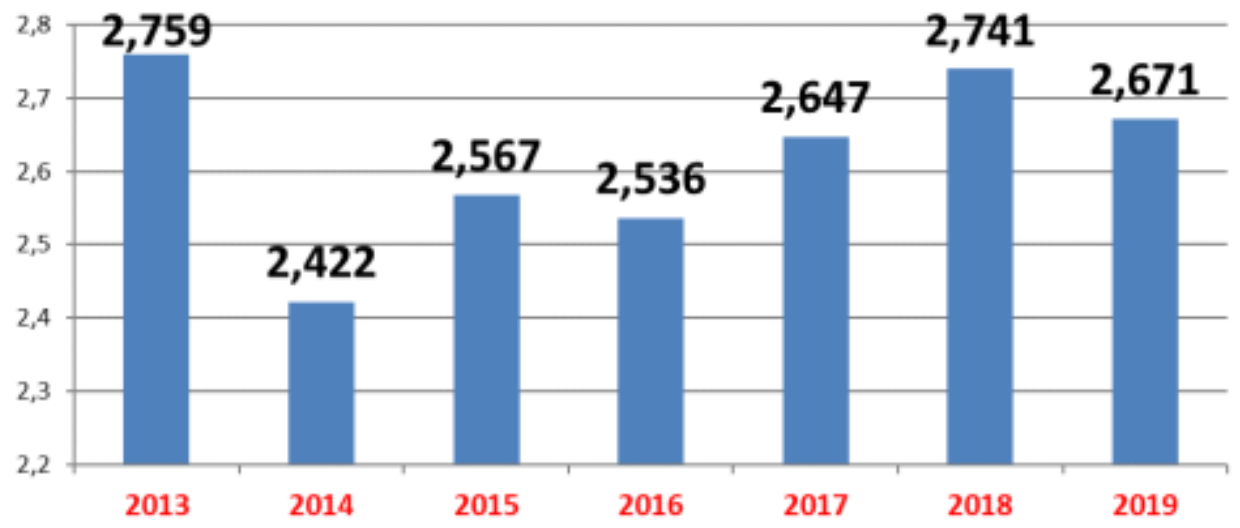

Рис. 2. Количество ночей пребывания франиузских туристов на территории острова Корсика в 2019 г., млн ночей Источник: Bilan économique 2019 - Corse (фр. Экономический доклад 2019 - Корсика) [3].

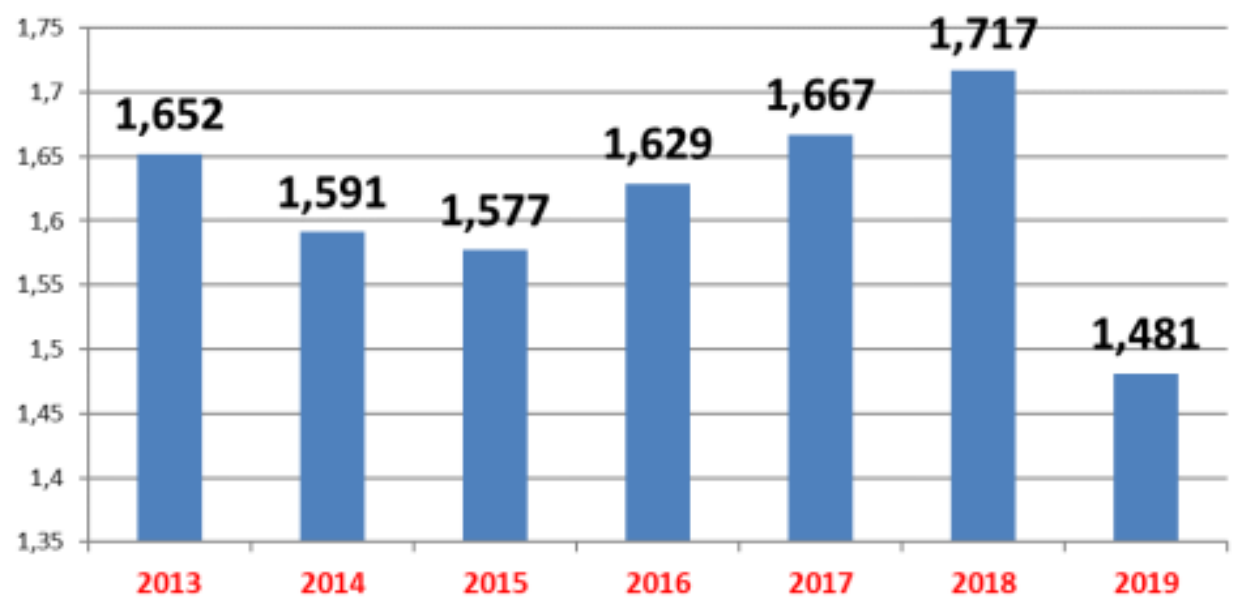

Pис. 3. Количество ночей пребывания зарубежных туристов на территории острова Корсика в 2019 г., млн ночей 
Для российских туристов остров Корсика не имеет статуса популярного туристического маршрута. Приобретение авиабилетов из Москвы и Санкт-Петербурга возможно с промежуточной стыковкой в Париже, стоимость авиабилетов на 100-200\% выше стоимости авиабилетов по направлениям Москва - Ницца, Москва - Марсель, Москва - Бордо. В докризисный 2019 г. стоимость авиабилета на рейс Москва - Ницца - Москва составляла от 13500 руб. (авиакомпания «S7»), стоимость авиаперелета по направлению Москва - Аяччо - Москва авиакомпании «Air France» с промежуточной стыковкой в аэропорту Шарль де Голль (Париж) превышала 35000 рублей. Ценовая разница является ключевым фактором невостребованности о. Корсика в качестве туристического направления для россиян.

Методы исследования. Вопросам развития региональных аэропортов посвящены труды российских и зарубежных ученых. В статье Пахорукова К.И. «Децентрализация во Франции: особая роль Корсики» [5] автор заключает, что власти Французской Республики уделяют незначительное внимание развитию туристического потенциала острова. В условиях развития туриндустрии как важной составляющей экономики стран Европейского Союза развитие туризма на острове Корсика могло бы оказать положительное влияние на снижение уровня безработицы и повышение благосостояния населения региона. В дополнение к результатам исследования автора необходимо отметить, что развитие туризма на итальянских островах Сицилия и Сардиния осуществляется более высокими темпами. Важную роль в этом играют аэропорты Сицилии и Сардинии, имеющие разветвленную внутреннюю и международную сеть. Ведущие бюджетные авиакомпании Европы имеют развитую маршрутную сеть на территории аэропортов итальянских островов [6]. Так, испанская бюджетная авиакомпания

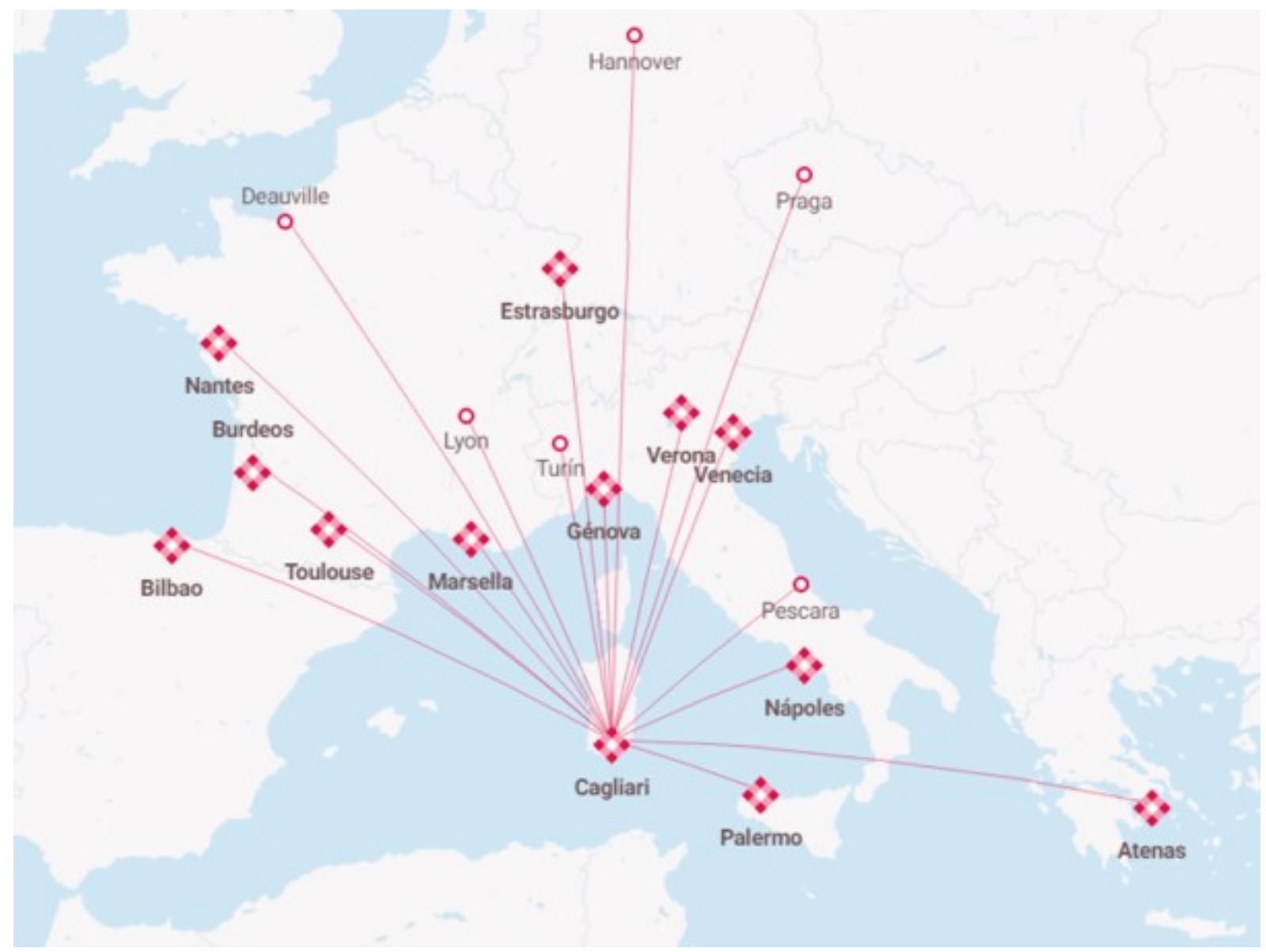

Puc. 4. Марирутная сеть испанской бюджетной авиакомпании «Volotea» на базе аэропорта Кальяри (о. Сардиния, Италия) по состоянию на 2021 г.

Источник: «Volotea». География полетов. Официальный сайт [7]. 
В статье Маленцевой П.С. и Тишкиной А.Г. «Условия и организация гастрономического туризма во Франции» [8] авторы исследования подчеркивают, что остров Корсика славится своим культурным и историческим наследием, но продолжает оставаться невостребованным для значительной части туристов, прибывающих во Францию. Между Корсикой действует авиасообщение с крупными городами Франции, а также городами Италии и Испании (рейсы выполняются бюджетными авиакомпаниями), вторым возможным способом добраться до острова является паромная переправа между островом и городами Ницца и Тулон.

С 1989 г. на территории острова осуществляет деятельность французская региональная авиакомпания «Air Corsica» [9], собственниками которой являются: Территориальное управление острова Корсика $(60,37 \%)$, франко-голландский авиационный холдинг «Air France KLM» $(11,94 \%)$, французская финансовая группа «Credit Agricole» $(7,55 \%)$, частная инвестиционная компания «SNCM» $(6,68 \%)$. Согласно данным, размещенным на официальном сайте авиаперевозчика (по состоянию на 27.01.2021 г.), стоимость авиабилетов из аэропортов Аяччо, Кальяри, Фигари, Бастия до Парижа (Орли) составляет 69 евро. Следует отметить для сравнения, что стоимость авиабилетов европейских бюджетных авиакомпаний на маршрутах малой протяженности (до 100 км) на аналогичный период составляет от 9 евро до 50 евро.

Анализ аэропортов острова Корсика. Сопоставим данные анализа маршрутной сети клас-

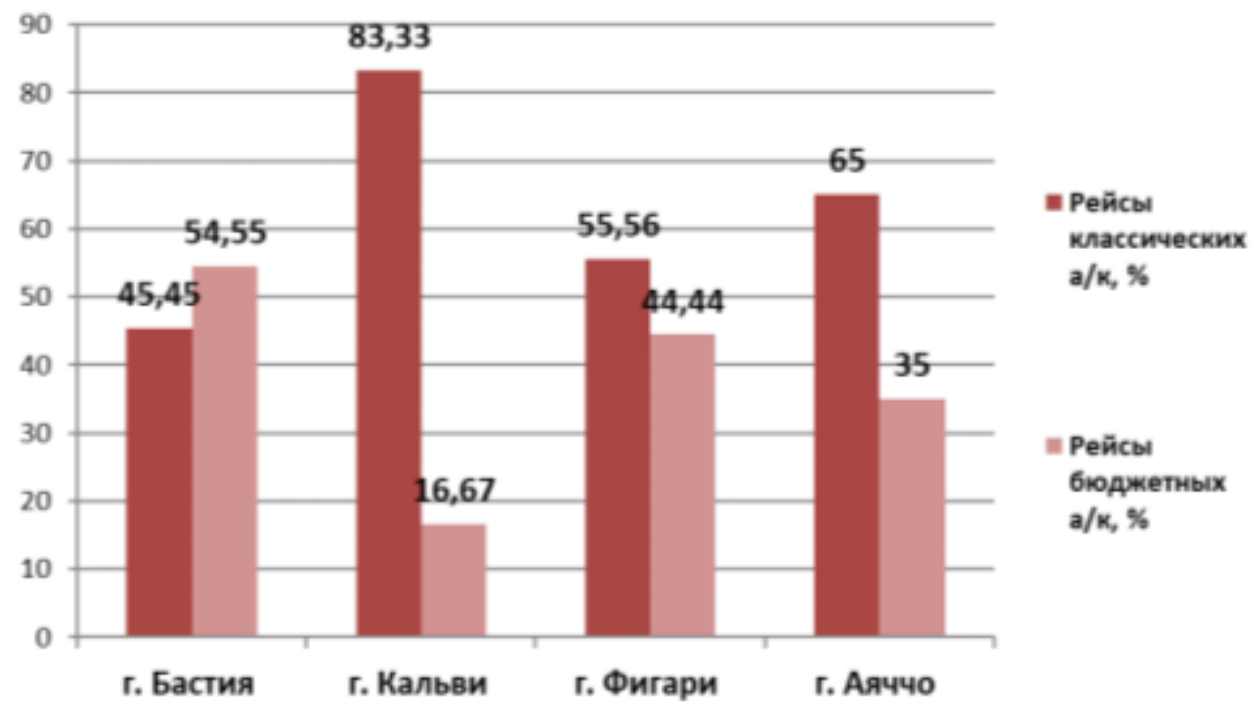

Pис. 5. Доля рейсов классических и бюджетных авиакомпаний в структуре марирутной сети аэропортов о. Корсика. Докризисный уровень, \% (январь 2020 г.)

Источник: Результаты деятельности аэропортов Франции в 2019 г. Статистика и трафик [1].

До кризиса 2020 г. аэропорты Корсики обслуживали регулярные рейсы европейских бюджетных авиакомпаний: «Ryanair» (Ирландия), «EasyJet» (Великобритания), «Volotea» (Испания), «Vueling» (Испания), «Transavia» (Франция - Нидерланды). Однако их доля в структуре маршрутной сети аэропортов была незначительной и составляла от 1 до 3 направлений с периодичностью от 1 до 4 рейсов в неделю.

В статье итальянского исследователя Ventisette Е. (ит. Ветисетте Э.) «Means of transport of foreign tourists in Italy and the tourism balance of payments» (англ. Транспортные средства иностранных туристов в Италии и баланс платежей по статье «туризм») [10] сделан вывод о том, что аэропорты Корсики проигрывают итальянским аэропортам Сардинии и Сицилии в развитости маршрутной сети, и это является препятствующим фактором в развитии туризма. Автор подчеркивает, что Правительство Италии, совместно с органами исполнительной власти Сицилии и Сардинии в период с 2008 по 2015 гг., инициировало реализацию комплекса мер по совершенствованию региональных аэропортов, а также расширило доступ иностранных авиакомпаний в островные регионы. Бюрократизация французских властей и непонимание структурных особенностей развития островных территорий оказывают негативное влияние и пре- 
пятствуют развитию корсиканских аэропортов.

Роль консолидации республиканских и региональных органов исполнительной власти оказала положительное влияние на развитие туризма в Испании [11]. На территории Испании были образованы две бюджетные авиакомпании «Vueling» и «Volotea», оказавшие положительное влияние на развитие национальной сферы туризма. Италия не имеет бюджетной авиакомпании, однако для ведущих европейских бюджетных авиакомпаний из Ирландии, Великобритании, Венгрии, Италии и Германии итальянский рынок является одним из приоритетных в структуре европейского рынка пассажирских авиаперевозок в бюджетном сегменте. Франкоголландский авиационный холдинг «Air France - KLM» владеет бюджетной авиакомпанией «Transavia», однако компания не имеет высоких темпов роста и развития; флот компании составляют 42 ед. Boeing 737-700 и Boeing 737-800 [12]. Для сравнения укажем, что флот ирландской бюджетной авиакомпании «Rуanair» составляют 442 ед. Boeing 737-800; британской «easyJet» - 332 ед. Airbus модификаций A-319, A-320, А-321. Увеличение доли рынка Франции в структуре бюджетных авиаперевозок возможно только благодаря многократному увеличению парка воздушных судов «Transavia» или благодаря созданию национальной бюджетной авиакомпании. Парк воздушных судов островной региональной авиакомпании «Air Corsica» составляют 9 ед. Airbus A-320-200 (вместимостью 180 пасс.), обслуживающие направления Корсика - Париж, в количестве 5 ед. и 4 ед. лайнера ATR-72-500 (вместимостью 70 пасс.), обслуживающих направления, связывающие Корсику с регионами Франции. Ребрендинг «Air Corsica» и переход авиакомпании в бюджетный сегмент является маловероятным сценарием развития. Испания и Италия не имеют региональных авиакомпаний, базирующихся на территории островной части государств. Пассажиропоток между Испанией и островами Майорка, Минорка, Канарскими обслуживается испанскими бюджетными авиакомпаниями «Vueling», «Volotea» и классической испанской авиакомпанией «Iberia». Пассажиропоток островов Сицилия, Сардиния, Лампедуза обслуживается итальянскими классическими авиакомпаниями «Alitalia» и «Air Italy», а также европейскими бюджетными и классическими авиаперевозчиками.

Необходимо вспомнить, что в результате последствий мирового финансового кризиса 2008 г. падение пассажиропотока не превышало 10\%. Кризис же 2020 г. оказал глобальное негативное влияние на мировой и европейский рынок пассажирских авиаперевозок. Падение пассажиропотока в 2020 г. составило 60\% к показателю 2019 года. Начиная с марта и до конца 2020 года были введены временные запретительные и ограничительные меры на выполнение международных авиарейсов. Регулярное авиасообщение между о. Корсика и материковой Францией осуществляется только авиакомпаниями «Air Corsica» и «Air France». На момент проведения исследования (январь 2021 г.) корсиканские аэропорты не осуществляли обслуживание регулярных рейсов, связывающих Корсику с зарубежными странами. Ограничения, действую-

\begin{tabular}{l|l|c|}
\hline \multicolumn{1}{|c|}{ Направление } & Авиакомпания & Тип авиакомпании \\
\hline г. Париж-Орли & $\begin{array}{c}\text { «Air Corsica» } \\
\text { «Air France» }\end{array}$ & $\begin{array}{l}\text { Классическая } \\
\text { Классическая }\end{array}$ \\
\hline г. Лион & «Air Corsica» & Классическая \\
\hline г. Марсель & «Air Corsica» & Классическая \\
\hline г. Ницца & «Air Corsica» & Классическая \\
*Источник: Официальный сайт аэропорта Бастия (о. Корсика) [13].
\end{tabular}

Таблица 3

\begin{tabular}{|l|c|c|}
\hline \multicolumn{1}{|c|}{ Направление } & Авиакомпания & Тип авиакомпании \\
\hline г. Париж - Орли & $\begin{array}{c}\text { «Air Corsica» } \\
\text { «Air France» }\end{array}$ & Классическая \\
\hline г. Марсель & «Air Corsica» & Классическая \\
\hline г. Ницца & «Air Corsica» & Классическая \\
\hline
\end{tabular}

*Источник: Официальный сайт аэропорта Кальви (о. Корсика) [14]. 


\begin{tabular}{|l|c|c|}
\hline \multicolumn{1}{|c|}{ Направление } & Авиакомпания & Тип авиакомпании \\
\hline г. Париж - Орли & $\begin{array}{l}\text { «Air Corsica» } \\
\text { «Air France» }\end{array}$ & $\begin{array}{l}\text { Классическая } \\
\text { Классическая }\end{array}$ \\
\hline г. Марсель & «Air Corsica» & Классическая \\
\hline г. Ницца & «Air Corsica» & Классическая \\
\hline
\end{tabular}

*Источник: Официальный сайт аэропорта Аяччо (о. Корсика) [15].

Таблица 5

\begin{tabular}{|l|c|c|}
\hline \multicolumn{1}{|c|}{ Направление } & Авиакомпания & Тип авиакомпании \\
\hline г. Париж - Орли & $\begin{array}{c}\text { «Air Corsica» } \\
\text { «Air France» }\end{array}$ & $\begin{array}{l}\text { Классическая } \\
\text { Классическая }\end{array}$ \\
\hline г. Марсель & «Air Corsica» & Классическая \\
\hline г. Тулон & «Air Corsica» & Классическая \\
\hline г. Ницца & «Air Corsica» & Классическая \\
\hline
\end{tabular}

*Источник: Официальный сайт аэропорта Фигари (о. Корсика) [16].

Сокращение маршрутной сети аэропортов Корсики носит временный характер и обусловлено введением ограничительных мер на осуществление регулярного пассажирского авиасообщения в период пандемии COVID-19. В случае улучшения эпидемиологической ситуации введенные ограничительные меры будут поэтапно сниматься. Важно отметить, что меры, введенные французскими властями, являются одними из самых жестких в рамках Европейского Союза [17]. В период с марта по май 2020 г. падение пассажиропотока достигало 90-95\% к аналогичному показателю 2019 г.

Выводы. Возможным вероятным сценарием развития является банкротство региональной французской авиакомпании «Air Corsica». Этот прогноз был сделан французским экспертом Антуаном Альбертани (фр. Antoin Albertani) в статье «Effondrement du transport et tourisme à l'arrêt : avec le Covid-19, la Corse redécouvre qu'elle est une île» (фр. Транспортный коллапс и туризм на останове: с Covid-19 Корсика вновь заявляет, что она является островом) [18]. Необходимо учитывать потери предприятий сферы туризма острова Корсика от введения временных ограничительных и запретительных мер на осуществление регулярного международного авиасообщения.

Эффективным сценарием посткризисного развития аэропортов о. Корсика является расширение действующей маршрутной сети международного авиасообщения. При разработке проекта посткризисного развития полезно учесть опыт Италии (на примере аэропорта Кальяри) в построении международной маршрутной сети. Рассмотрим подробнее данный пример и представим данные международной маршрутной сети аэропорта Кальяри по состоянию на 2021 г. (табл. 6).

Мы видим, что доминирующее положение в структуре маршрутной сети аэропорта Кальяри - Элмас (остров Сардиния, Республика Италия) занимают направления бюджетных авиакомпаний. Пассажиропоток аэропорта Кальяри - Элмас по итогам работы за 2019 г. составил 4,747 млн пасс. [20], что превышает совокупный пассажиропоток 4 аэропортов острова Корсика $-4,263$ млн пасс. за аналогичный период. 
РУБЛЕВ В.В. ЛАРИН О.Н.

ПЕРСПЕКТИВЫ РАЗВИТИЯ АЭРОПОРТОВ ОСТРОВА КОРСИКА (ФРАНЦИЯ) В УСЛОВИИ МАКРОЭКОНОМИЧЕСКОЙ НЕСТАБИЛЬНОСТИ

Таблица 6

\begin{tabular}{|c|c|c|}
\hline Направление & Авиакомпания & Тип авиакомпании \\
\hline Аликанте & «Ryanair» & Бюджетная \\
\hline Гамбург & «Eurowings» & Бюджетная \\
\hline Амстердам & «KLM» & Классическая \\
\hline Афины & «Volotea» & Бюджетная \\
\hline Барселона & $\begin{array}{l}\text { «Vueling» } \\
\text { «Ryanair» }\end{array}$ & $\begin{array}{l}\text { Бюджетная } \\
\text { Бюджетная }\end{array}$ \\
\hline Базилия & «easyJet» & Бюджетная \\
\hline Берлин & «easyJet» & Бюджетная \\
\hline Бильбао & «Volotea» & Бюджетная \\
\hline Бордо & «Volotea» & Бюджетная \\
\hline Бреславия & «Ryanair» & Бюджетная \\
\hline Брюссель & «Ryanair» & Бюджетная \\
\hline Будапешт & «Ryanair» & Бюджетная \\
\hline Колонья & «Eurowings» & Бюджетная \\
\hline Краковица & «Ryanair» & Бюджетная \\
\hline Дёвиль & «Volotea» & Бюджетная \\
\hline Дублин & «Ryanair» & Бюджетная \\
\hline Дюссельдорф & $\begin{array}{c}\text { «Ryanair» } \\
\text { «Eurowings» }\end{array}$ & $\begin{array}{l}\text { Бюджетная } \\
\text { Бюджетная }\end{array}$ \\
\hline Франкфурт-на-Майне & $\begin{array}{l}\text { «Lufthansa» } \\
\text { «Condor» } \\
\text { «Ryanair» } \\
\end{array}$ & $\begin{array}{c}\text { Классическая } \\
\text { Чартерная } \\
\text { Бюджетная }\end{array}$ \\
\hline Женева & «easyJet» & Бюджетная \\
\hline Ганновер & «Volotea» & Бюджетная \\
\hline Карлсруэ - Баден & «Ryanair» & Бюджетная \\
\hline Лиль & «Tui Fly» & Чартерная \\
\hline Лион & «Volotea» & Бюджетная \\
\hline Лондон & $\begin{array}{c}\text { «British Airways» } \\
\text { «Ryanair» } \\
\text { «easyJet» }\end{array}$ & $\begin{array}{c}\text { Классическая } \\
\text { Бюджетная } \\
\text { Бюджетная }\end{array}$ \\
\hline Люксембург & «Luxair» & Классическая \\
\hline Мадрид & $\begin{array}{c}\text { «Ryanair» } \\
\text { «Iberia» }\end{array}$ & $\begin{array}{c}\text { Бюджетная } \\
\text { Классическая }\end{array}$ \\
\hline Мальта & «Air Malta» & Классическая \\
\hline Манчестер & «Ryanair» & Бюджетная \\
\hline Марсель & «Volotea» & Бюджетная \\
\hline Москва & «S7» & Классическая \\
\hline Нант & «Volotea» & Бюджетная \\
\hline Ницца & «easyJet» & Бюджетная \\
\hline Прага & $\begin{array}{c}\text { «Volotea» } \\
\text { «Smartwings» }\end{array}$ & $\begin{array}{l}\text { Бюджетная } \\
\text { Бюджетная }\end{array}$ \\
\hline Париж & $\begin{array}{c}\text { «Ryanair» } \\
\text { «Air France» } \\
\text { «Tui Fly» } \\
\text { «easyJet» }\end{array}$ & $\begin{array}{c}\text { Бюджетная } \\
\text { Классическая } \\
\text { Чартерная } \\
\text { Бюджетная }\end{array}$ \\
\hline Порту & «Ryanair» & Бюджетная \\
\hline Севилья & «Ryanair» & Бюджетная \\
\hline Стоккарда & «Eurowings» & Бюджетная \\
\hline Страсбург & «Volotea» & Бюджетная \\
\hline Тулуза & $\begin{array}{l}\text { «Volotea» } \\
\text { «easyJet» }\end{array}$ & $\begin{array}{l}\text { Бюджетная } \\
\text { Бюджетная }\end{array}$ \\
\hline Валенсия & «Ryanair» & Бюджетная \\
\hline Варсавия & «Ryanair» & Бюджетная \\
\hline Вена & $\begin{array}{l}\text { «Ryanair» } \\
\text { «Austrian» }\end{array}$ & $\begin{array}{c}\text { Бюджетная } \\
\text { Классическая } \\
\end{array}$ \\
\hline Цюрих & «Edelweiss» & Чартерная \\
\hline
\end{tabular}

*Источник: Cagliari Airport. Destinazioni (ит. Аэропорт Кальяри. Направления) [19]. 


\section{Лuтература}

1. Resultats d'activite des aeroports francais - 2019. Statistiques de traffic (фрр. Результать деятельности аэропортов Франции в 2019 г. Статистика и трафик) // UAF\&FRA (Union des Aeroports Francais \& Francophones Associes). 2020.

2. Carte touristique de la Corse (фp. Туристическая карта Корсики) [Электронный ресурс]. - URL : https://www.bonifacio.fr/brochures/carte-touristique-de-corsel (дата обрамения: 28.01.2021).

3. Bilan économique 2019 - Corse (фр. Экономический доклад 2019 - Корсика) [Электронный ресурс]. URL : https://www.insee. fr/fr/statistiques/4475858? sommaire $=4475962$ (дата обрашения: 28.01.2021).

4. Остров Корсика. Туристический информационный портал Республики Казахстан [Электронный pecypc]. - URL : https://ru.qaz.wiki/wiki/Corsica (дата обращения: 28.01.2021).

5. Пахоруков, К. И. Децентрализачия во Франции : особая роль Корсики // Всероссийский журнал научных публикаиий. 2011. №7 (8). С.69-71.

6. Рублев, В. В. Региональная маршрутная сеть как основа конщепщии бюджетной авиакомпании : европейский опыт и российская практика // Современная экономика : проблемы и решения. - Воронеж, 2020. №10 (130) (октябрь). C.150-168.

7. «Volotea». География полетов. Официальный сайт [Электронный ресурс]. - URL : https:// www.volotea.com/es/destinos/ (дата обращчения: 28.01.2021).

8. Маленцова, П. С., Тишкина, А. Г. Условия и организащия гастрономического туризма во Франции // Парадигма. 2018. № 28. С.112-121.

9. «Air Corsica - франиузская региональная авиакомпания». Офиџиальный сайт [Электронный ресурс]. - URL : https://www.aircorsica.com/ (дата обрашения: 28.01.2021).

10. Ventisette, E. Means of transport of foreign tourists in Italy and the tourism balance of payments // Tourism and hospitality management. 2019. No. 25 (2). P. 247-268.

11. Рублев, В. В. Анализ влияния бюджетных авиакомпаний «Volotea» и «Vueling» на рынок пассажирских авиаперевозок Испании в условиях макроэкономической нестабильности // Теоретическая экономика. Ярославский государственный технический университет. 2020. №11 (71) (ноябрь). С. 68-78.

12. Transavia. Официальный сайт. Русская версия [Электронный ресурс]. - URL : https:// www.transavia.com/fr-FR/accueil/ (дата обращения: 28.01.2021).

13. Aéroport Bastia Poretta ( bastia.aeroport.fr/en/ (дата обращения: 28.01.2021).

14. Aéroport de Calvi (фp. Аэропорт Кальви) [Электронный ресурс]. - URL : http://calvi.aeroport.fr/en/ (дата обращения: 28.01.2021).

15. Aéroport d'Ajaccio Napoléon Bonaparte ( $p$ p. Аэропорт Аяччо им. Наполеона Бонапарта) [Электронный ресурс]. - URL : http://www.2a.cci.fr/Aeroport-Napoleon-Bonaparte-Ajaccio.html (dama обрамения: 28.01.2021).

16. Aéroport Figari (фp. Аэропорт Фигари) [Электронньій ресурс]. - URL : http://www.2a.cci.fr/AeroportFigari-Sud-Corse.html (дата обращения: 28.01.2021).

17. Власти Франциии продлили действие жестких антикоронавирусных ограничений. ИНТЕРФАКС [Электронный ресурс]. - URL : https://www.interfax.ru/world/744301 (дата обращения: 28.01.2021).

17. Antoin Albertani Effondrement du transport et tourisme à l'arrêt : avec le Covid-19, la Corse redécouvre qu'elle est une île [Электронный ресурс]. - URL : https://www.lemonde.fr/economie/article/2021/01/07/lecovid-19-frappe-au-c-ur-l-economie-corse_6065468 3234.html (дата обращения: 28.01.2021).

19. Cagliari Airport. Destinazioni (um. Аэропорт Кальяри. Направления). [Электронный ресурс]. - URL : http://www.sogaer.it/it (дата обращения: 28.01.2021).

20. Cagliari Airport. Analisi statistiche di traffico - 2019 (ит. Аэропорт Кальяри. Анализ авиационной статистики за 2019 г.) [Электронный ресурс]. - URL : http://www.sogaer.it/it/societa-trasparente (dama oбращеени: 29.01.2021).

\section{References:}

1. Resultats d'activite des aeroports francais - 2019. Statistiques de traffic (fr. Rezul'taty deyatel'nosti aeroportov Francii v 2019 g. Statistika i trafik) // UAF\&FRA (Union des Aeroports Francais \& Francophones Associes). 2020

2. Carte touristique de la Corse (fr. Turisticheskaya karta Korsiki) [Elektronnyj resurs]. - URL : https:// www.bonifacio.fr/brochures/carte-touristique-de-corsel (data obrashcheniya: 28.01.2021).

3. Bilan économique 2019 - Corse (fr. Ekonomicheskij doklad 2019 - Korsika) [Elektronnyj resurs]. - URL : https://www.insee.fr/fr/statistiques/4475858?sommaire $=4475962$ (data obrashcheniya: 28.01 .2021 ).

4. Ostrov Korsika. Turisticheskij informacionnyj portal Respubliki Kazahstan [Elektronnyj resurs]. - URL . https://ru.qaz.wiki/wiki/Corsica (data obrashcheniya: 28.01.2021).

5. Pahorukov, K. I. Decentralizaciya vo Francii : osobaya rol' Korsiki // Vserossijskij zhurnal nauchnyh publikacij. 2011. №7 (8). S.69-71.

6. Rublev, $V$. V. Regional'naya marshrutnaya set' kak osnova koncepcii byudzhetnoj aviakompanii : evropejskij opyt i rossijskaya praktika // Sovremennaya ekonomika : problemy i resheniya. - Voronezh, 2020. №10 (130) (oktyabr'). S.150-168.

7. "Volotea». Geografiya poletov. Oficial'nyj sajt [Elektronnyj resurs]. - URL : https://www.volotea.com/es/ destinos/(data obrashcheniya: 28.01.2021).

8. Malencova, P. S., Tishkina, A. G. Usloviya i organizaciya gastronomicheskogo turizma vo Francii // Paradigma. 2018. № 28. S.112-121.

9. «Air Corsica - francuzskaya regional'naya aviakompaniya». Oficial'nyj sajt [Elektronnyj resurs]. - URL : 
https://www.aircorsica.com/ (data obrashcheniya: 28.01.2021).

10. Ventisette, E. Means of transport of foreign tourists in Italy and the tourism balance of payments // Tourism and hospitality management. 2019. No. 25 (2). P. 247-268.

11. Rublev, V. V. Analiz vliyaniya byudzhetnyh aviakompanij «Volotea» $i$ "Vueling» na rynok passazhirskih aviaperevozok Ispanii v usloviyah makroekonomicheskoj nestabil'nosti // Teoreticheskaya ekonomika. YAroslavskij gosudarstvennyj tekhnicheskij universitet. 2020. №11 (71) (noyabr'). S. 68-78.

12. Transavia. Oficial'nyj sajt. Russkaya versiya [Elektronnyj resurs]. - URL : https://www.transavia.com/frFR/accueil/ (data obrashcheniya: 28.01.2021).

13. Aéroport Bastia Poretta (fr. Aeroport Bastiya - Poretta) [Elektronnyj resurs]. - URL : http:// bastia.aeroport.fr/en/ (data obrashcheniya: 28.01.2021).

14. Aéroport de Calvi (fr. Aeroport Kal'vi) [Elektronnyj resurs]. - URL : http://calvi.aeroport.fr/en/ (data obrashcheniya: 28.01.2021).

15. Aéroport d'Ajaccio Napoléon Bonaparte (fr. Aeroport Ayachcho im. Napoleona Bonaparta) [Elektronnyj resurs]. - URL : http://www.2a.cci.fr/Aeroport-Napoleon-Bonaparte-Ajaccio.html (data obrashcheniya: 28.01.2021).

16. Aéroport Figari (fr. Aeroport Figari) [Elektronnyj resurs]. - URL : http://www.2a.cci.fr/Aeroport-FigariSud-Corse.html (data obrashcheniya: 28.01.2021).

17. Vlasti Francii prodlili dejstvie zhestkih antikoronavirusnyh ogranichenij. INTERFAKS [Elektronnyj resurs]. - URL : https://www.interfax.ru/world/744301 (data obrashcheniya: 28.01.2021).

17. Antoin Albertani Effondrement du transport et tourisme à l'arrêt : avec le Covid-19, la Corse redécouvre qu'elle est une île [Elektronnyj resurs]. - URL : https://www.lemonde.fr/economie/article/2021/01/07/le-covid -19-frappe-au-c-ur-l-economie-corse_6065468_3234.html (data obrashcheniya: 28.01.2021).

19. Cagliari Airport. Destinazioni (it. Aeroport Kal'yari. Napravleniya). [Elektronnyj resurs]. - URL : http:// www.sogaer.it/it (data obrashcheniya: 28.01.2021).

20. Cagliari Airport. Analisi statistiche di traffico - 2019 (it. Aeroport Kal'yari. Analiz aviacionnoj statistiki za 2019 g.) [Elektronnyj resurs]. - URL : http://www.sogaer.it/it/societa-trasparente (data obrashcheniya. 29.01.2021). 